\title{
Between Danger and Pleasure: Rethinking the Imperilled Filipina Migrant Body in Jose Dalisay's Soledad's Sister
}

\author{
GRACE V.S. CHIN \\ English Language and Literature Studies, School of Humanities, \\ Universiti Sains Malaysia, 11800 USM Pulau Pinang, Malaysia \\ grace.chin@usm.my
}

Published online: 20 December 2018

To cite this article: Chin, Grace V.S. 2018. Between danger and pleasure: Rethinking the imperilled Filipina migrant body in Jose Dalisay's Soledad's Sister. KEMANUSIAAN the Asian Journal of Humanities 25(Supp. 1): 121-142, https://doi.org/10.21315/kajh2018.25.s1.7

To link to this article: https://doi.org/10.21315/kajh2018.25.s1.7

\begin{abstract}
This article explores the complexities and tensions of negotiating female agency and freedom by examining the theme of danger and pleasure through the representation of the Filipina migrant body in Jose Dalisay's Soledad's Sister. Of interest here is the Filipina migrant body's negotiation between the danger posed by the patriarchal systems of the global economy and the pleasure of self- and sexual discovery, for it highlights the empowering possibilities and opportunities that can be found in the very same transnational spaces where dangers also lurk. Subjected to local and global patriarchal discourses including motherhood and martyrdom - and their prescribed limits, the Filipina migrant body is rendered marginal, displaced and inferior. Despite these limits however, I argue that the migrant body-in-transition should be considered a corporeal "third" space that holds multiple meanings and liminal possibilities that can engender significant changes in identity, voice and agency. Using postcolonial and gender theories, this article problematises the prevailing, authoritative discourses on migrant identity, subjection and subjectivity by showing how the novel undermines essentialist assumptions associated with the stereotyped helper through the exploration of sexual pleasure in the dangerous phallocentric spaces of the global economy.
\end{abstract}

Keywords and phrases: Filipina migrant body, gender, sexuality, Philippine literature, domestic helper

\section{Introduction}

On a cloud-curtained evening, one Saturday in August, a corpse arrived in a zinc casket in a wooden crate at Ninoy Aquino International Airport, 237 kilometers west of Paez. The cargo manifest put the dead woman's name down as "Cabahug, Aurora V." At 1834 hours, just as the city's drivers began switching their headlights on and a million gas stoves 
roared to life, Aurora V. Cabahug's flight rejoined the earth, although the woman herself did not, just yet; she lay deep in the Gulf Air 747's cargo bay where it was coldest, a bulkhead away from the tiger orchids and the apricots. (Dalisay 2008, 2)

The opening lines to Jose Dalisay's award-winning novel Soledad's Sister (2008) draw on a leitmotif familiar to the national narratives of the Philippines since the 1970s, that of the commodified and feminised bodies of overseas Filipino workers (OFWs) whose returning corpses - about 600 per year - is so commonplace it has become "the same old story [that] keeps repeating itself" (Dalisay 2010, 173). By alluding to this recurring trope, Dalisay highlights a theme central to the OFW discourse: the imperilled state of the third-world migrant body trapped in a vicious cycle of inferiority, servitude, and marginalisation as a gendered "servant" (Parreñas 2001a) in the patriarchal regimes of the global economy. The "same old story [that] keeps repeating itself" is the circulating, reproductive sign of an embattled migrant body inscribed as the recurring site of traumatic violence and upon which ideological wars are waged in the name of nation, culture, late capitalism and globalisation. Significantly too, the migrant body under scrutiny here is inherently sexed/gendered, for it is the Filipina body that is more vulnerable to all forms of violence, including sexual exploitation, harassment, abuse, rape and murder:

These suicides, as well as the mysterious deaths of Filipina overseas contract workers whose corpses are shipped back to the Philippines in both increasing and increasingly unremarked-upon numbers; the murder and mutilation of Filipinas in the hands of strangers, lovers, husbands, fathers, brothers, friends, clients, and employers; and the systematic gendered, sexualized, racialized, and class-based killing and injuring of Filipinas everywhere are to me material testaments of wars for which Filipinas are the casualties and the means, the fuel, the fodder, and the weaponry. (Tadiar 2005, 376)

Tadiar's observation above not only captures the prevailing gender formations, patterns and processes in the global labour economy but also how they exploit Filipina bodies for the pleasures of the consumer markets, both at home and abroad - a phenomenon that Tolentino calls the "vaginal economy" (2011). These markets in fact reify entrenched feminine identities and roles through occupational stereotypes like the domestic helper and sex worker: while the former valorises woman's traditional, "innate" femininity through the discourses of domesticity and motherhood, the latter falls back on the age-old sexual objectification and commodification of the female body. Inasmuch as the Filipina migrant worker is a reproductive commodity for the global nexus of capitalistic-patriarchal markets, 
she is also a precious source of revenue for the national economy. Subjected to multiple discursive patriarchal binds - both local and global - that hold it to positions of inferiority, marginality and powerlessness, the Filipina migrant worker as an individual body is, as noted by Tadiar earlier, especially vulnerable to the ever-present sexual and physical dangers of the immigrant world. Caught within the narrow constraints posed by the tightly regulated state and sociocultural boundaries of local and global economies, the Filipina migrant worker is not only marginalised in terms of gender, sexuality, race and class, but she also occupies a tenuous position as a displaced, partial citizen who is deprived of full political agency and rights in the host country (Parreñas 2001a, 48-51). In this situation, how does she negotiate voice, agency and freedom? This, then, is the key question raised in my reading of Soledad's Sister, which powerfully imagines and articulates this negotiation through the portrayal of a domestic helper's discovery of sexual pleasure.

This essay problematises the established, authoritative discourses on migrant identity, subjection, and subjectivity by examining the tensions and complexities of negotiating female agency and freedom through the theme of danger and pleasure in Soledad's Sister. This theme has held a special place in predominantly white feminist studies since Vance's influential volume on woman's sexuality, which is defined as double-edged: it is "simultaneously a domain of restriction, repression, and danger as well as a domain of exploration, pleasure, and agency" $(1984,1)$. Sexuality is inextricably linked to agency for it involves the right to one's body and the choices made with regard to it, including the right to say yes or no to sex. In patriarchal societies however, the reality is that the female body is subjected to prevailing practices and discourses of sexual objectification, judging and shaming, and gendered forms of violence, all of which function as a means of stripping women of their agency, power, even their voice and identity.

Where the Filipina migrant body is concerned, the complications are multiplied in the conservative, patriarchal contexts of Southeast Asia where women's bodies are still tied to the collectivist identity of family and community, and subjected to religious and social discourses of morality and virtue. This point is particularly relevant to the Philippines, where sexual experiences are informed by Roman Catholicism and socially-upheld (double) standards of morality in which "virginity is associated with a woman's honor and virility is a symbol of manhood" (Delgado-Infante and Ofreneo 2014, 391). Within the global economy, the Filipina migrant worker is often associated with negative sexual stereotypes that include the prostitute and mail-order bride, not to mention the domestic helper who is also the scheming flirt or seductress who steals husbands and fathers, and wrecks homes, marriages and families (Constable 1997). Because of these negative 
sentiments and perceptions, the Filipina migrant worker's expression and pursuit of pleasure, especially of a sexual nature, can be very dangerous; it may result in shame and guilt, and expose her to violence, abuse and even death, a point brought home to the reader at the start of the novel. This point is also highlighted by media representations and images associated with the female OFW, for it is the abused or violated Filipina body that is most visible and prevalent.

While mindful of the very real difficulties and dangers faced by women working abroad, I nonetheless argue for the need to rethink the stereotype of the Filipina migrant worker as a helpless and marginalised victim for such a position also glosses over the possibilities and opportunities for personal growth and transformation in the global labour economy. Studies in the field reveal that the lives of Filipina migrant workers have changed and are changing due to the power of financial independence, seen in the shifting patterns of household identities and responsibilities as increasing numbers of women shoulder the duty as the primary family breadwinner, a role conventionally performed by men (Parreñas 2001c; 2005). Away from their families and country, these women have access to opportunities not readily available to them at home; these opportunities have led to the reinvention and transformation of femininities and identities that should be considered affirming experiences and articulations of freedom and agency. In Soledad's Sister, the discovery of sexual pleasure not only becomes one such affirming expression of female power and agency, it also signifies the body's transformative potential, a key point in my analysis that will be discussed later.

There is therefore a need for a more nuanced understanding of the double-edged complexities and tensions emerging from the intersections of global and local discourses and experiences, and how they contribute to the shaping of the female migrant identity and subjectivity. On the one hand, there is the constant threat of sexual danger, but on the other hand, there is the promise of financial rewards and personal growth; the latter involves individual experiences of freedom and agency. These conflicting pull-push factors are reflected in the novel through the titular character Soledad Cabahug, whose negotiation of sexual agency and individual freedom ultimately exacts a high price. Soledad thus represents the imperilled body of every Filipina who enters the global labour economy, for the opportunities and possibilities that form the basis of her hopes and desires are found in the very same spaces where dangers also lurk. Furthermore, there are inherent tensions that arise from pursuing sexual pleasure and freedom as the female OFW still has to conform to the feminised identities and subject positions engendered by both state and sociocultural collectives of the global economy, be it mother, citizen, employee or commodity; these gender roles and identity-labels exact specific "duties" or "obligations" that regulate and discipline migrant identity and body within the "safe" limits of prescribed boundaries. 
Key to the articulations and negotiations of pleasure and danger is the sexed/ gendered body, which can be used to tease out the complex relations, practices and meanings of migrant subjection and subjectivity. As the sexed/gendered body forms the material and metaphorical site on which the dialectics between power and subjection, and the individual struggle for expression and agency are engaged, it can thus be used to develop my framework on the embodied boundaries and liminal possibilities of the "third" space, a concept expanded by Homi K. Bhabha (1990) who theorises cultural hybridity as a continuous social process borne of migrant encounters in global, diasporic contexts. Moving across boundaries and between transnational centres, the migrant body is the only constant that connects varying locations even as it intersects private and public, local and global territories and imaginaries of power; its ambiguous in-between spatial positioning not only establishes the gendered subject's frame of reference but also forms the fluid, transitory space from which the potential of the subjective self and its myriad liminal possibilities - including alternative imaginings, transformative identities, and the empowering affirmations of agency and freedom - can be realised. In other words, the body's lived experiences of "disjunctive, differential social positions" (Bhabha 1990, 220) in the "third space" are vital to the gendered subject's mediation of sexual pleasure as an expression of the individual self. It is for this reason that I describe the migrant body as an embodied third space.

As the corporeal manifestation of the third space and its liminal possibilities, the Filipina migrant body also constitutes an unstable body-in-transition that engages the social and cultural processes of hybridity through flux and change. The embodied third space is thus an enabling, liberating hybrid space that not only "displaces the histories that constitute it, and sets up new structures of authority, new political initiatives" (Bhabha 1990, 211) but is also in itself an interventionist strategy that can resist, subvert and disrupt the phallocentric, globalising gaze and its stereotyped assumptions and prescriptions of gender and sexuality since it "gives rise to something different, something new and unrecognizable, a new area of negotiation of meaning and representation" (Bhabha 1990, 211). This point correlates with Grosz's postulation of bodies as "centers of perspective, insight, reflection, desire, [and] agency" that "function interactively and productively. They act and react. They generate what is new, surprising, unpredictable" (1994, xi). This description aptly captures the transformative possibilities and subversive potential of the Filipina body already positioned in the indefinable fringes and in-between spaces of diasporic societies, and whose experience of transitional states is heightened by its mobility across transnational borders and margins. 
At the same time, I also consider Foucault's concept of the body as a discursive construct of specific historical, sociocultural, and geopolitical processes and contexts, a concept that not only challenges the positivist underpinnings of the third space and its liminal possibilities but also suggests that there are limits to these possibilities - a point raised earlier. One of the most famous corporeal theories that engages Foucauldian insights in developing a framework for gender identities is Judith Butler's gender performativity (1990), which conceives identity as an embodied "set of boundaries, individual and social, politically signified and maintained" (33) by "stylized repetition of acts" (140). Since the body's performance in the social arena is "at once a reenactment and reexperiencing of a set of meanings already socially established" (Butler 1990, 140), all material forms of individual agency and action, including self-expression and resistance, are therefore mediated through the rules of prohibition and boundaries operating within the system. These discursive rules and boundaries are signified by ritual behaviour, codes of conduct, social politeness and manners, and other embodied practices; all play a role in what Butler calls the body's performative identity as they regulate the gendered migrant body into disciplined corporeality. In Soledad's Sister, these rules and boundaries are represented by informal, everyday social practices, through which power hierarchies and gendered meanings are instituted, sustained and perpetuated, such as the performances of servitude and motherhood. Then there are the formal, institutionalised practices in the novel, denoted by the Catholic rites of prayer and penance that reify the ideologies of selfless motherhood and migrant heroism.

\section{Heroism, Martyrdom and Motherhood}

Before entering the analysis, I wish to first examine the mélange of contextual forces that construct and produce the identity and position of the Filipina helper in the nation space, if only to further enhance our understanding of the multiple discourses - historical, religious, political and social - at work in the novel. As mentioned earlier, Filipina migrant identities and femininities are shaped by essentialist assumptions of woman's nurturing, maternal nature and self-sacrifice, represented by the acts of "caring for others, of extending oneself to others, of serving and accommodating others" (Tadiar 2005, 377), both at home and abroad. In the global service economy, it is the figure of the domestic helper who makes visible the hegemonic discourse of performative motherhood, based on "the script of "maternalism and deference"" (Parreñas 2001b, 364). The Filipina helper is also representative of the feminisation of the migrant workforce - or, as noted earlier, the vaginal economy - that is driven not only by women's dominant numbers (ranging anywhere from between $50 \%$ and $70 \%$ in the last 25 years; see Tolentino 
2011) but also involves the "embodied practices, affect, emotions and feelings" (quoted in Tolentino 2011, 232) that make up the OFW experience, including that of the male labour.

The commodification of OFW bodies has been instrumental to the country's economic development policy and strategy since 1974, when - under the rule of President Marcos - the large-scale formation and mobilisation of the migrant workforce began. Regarded as the country's "most profitable export" (Rodriguez 2002, 349), the OFWs have been constructed and regulated first as an essential component of the state's national economy under Marcos, and later as part of the state's agenda in the global arena under the successive presidencies (see Tolentino 2011). In short, the production of the OFW body as exploited, marginalised Other that is slated for "3D" (domestic, degrading and demeaning) jobs is mandated at the highest levels of the state and supported by neoliberal globalisation. As of 2017, there are approximately 2.3 million OFWs deployed across the world (Philippine Statistics Authority 2018), with women making up the majority at 53.7 percent. About two-thirds work as domestic helpers since women's labour is driven by the global demand for care workers. Filipina helpers alone can be found in 160 countries worldwide; all are engaged in the business of domestic caregiving and mothering through the embodied practices of cooking, child rearing and doing household chores (Parreñas 2008).

Performative motherhood as a discourse is also upheld by the politics of "home" or the nation-state, where the Filipina is subjected to the dominant ideologies of family - a politicised symbol that is defended by the Philippine Constitution as the "foundation of the nation" (Article XV Sec. 1) - and Roman Catholicism, both of which regulate gender hierarchies, relations and practices that underline the local construction of femininities as mother, wife and daughter. While women's traditional identities and roles have been expanded and made more equitable to their male counterparts under the revisions of the 1987 Family Code in that they can - among other allowances - exercise the right to seek occupation outside the home, independently acquire property without a husband's consent, and remarry without losing parental control over their children (Ezer et al. 2011, 22), the reality has proven to be much more restrictive. There is widespread disapproval of migrant mothers whose long absences from home have been blamed as the main cause of broken families, divorces and unruly teenagers. According to Rodriguez (2005), such strong public sentiments stem from the perception that the female OFWs "[undermined] the social and moral fabric of family in the Philippines because [they] failed to perform traditional feminine roles" (11). 
Despite the underlying social censure of migrant mothers, these women are nonetheless valued for their vital economic contributions to their families as well as the country's coffers; their remittances are estimated to be in the billions annually. As a result, the state has recognised the OFW as "new national heroes" or bagong bayani in Tagalog, a state ideology that interpellates the OFWs into performing their "duty" as "self-sacrificing, nationalist martyrs ... to normalize migration and migrants' faithful remittance-sending to the homeland" (Rodriguez 2005, 6). Rodriguez (2002) also points out that the OFWs are disciplined and produced as good citizens who should discharge their patriotic duties to the "family, employer, host state and the Philippine government" (348) and, more importantly, "to identify with the country" (348). Duty thus rests upon the emotional ties of identification, remembrance and belonging with the imagined homeland, a vision that fuses the family, home, and nation as one and the same in the OFW discourse. It is also worth noting the religious undertones of migrant heroism as a state ideology, for it taps into Catholic concepts of suffering and sacrifice in order to bind individual OFW bodies to the collective body-politic of the homeland as "self-sacrificing, nationalist martyrs".

However, the figure of the suffering martyr is hardly new in the Filipino imaginary. It is embedded in the discourses of nationalism and historically validated by established literary canons, including the writings of the country's most revered anti-colonial heroes, Andres Bonifacio and Jose Rizal (the latter is known as the father of Filipino nationalism), both of whom had died for the revolutionary cause. As Dalisay Jr. (2007) states:

What seems particular to the Filipino is our Roman Catholic notion of suffering and sacrifice as prerequisites to salvation. In a sense, our heroes are those who can bear their crosses and endure-indeed, invite - terrible pain. The crucified Christ and the mater dolorosa are iconic figures in our literature and art. ... Our literature and poetry then are an articulation of suffering for freedom and salvation, in both a collective and personal sense.

The Catholic notion of suffering and sacrifice carries a particularly powerful historical and cultural resonance for the Filipino collectivity and psyche. In his 1951 article "Our Choice of Heroes”, Leon Ma. Guerrero, Jose Rizal's biographer, states that:

Filipinos do not value failure, or for that matter tragedy, for its own sake, but only insofar as these are submerged into the larger end of sacrifice. ... We save our highest homage and deepest love for the Christ-like victims whose mission is to consummate by their tragic 'failure' the redemption of our nation. (Quoted in Dalisay Jr. 2007) 
By drawing on the trope of Catholic martyrdom, this ideology re-imagines and rewrites the narratives of female self-sacrifice and servitude as narratives that hold religious value and ultimately, redemptive, heroic power. Domestic helpers are thus represented as a "Christ-like victims" who suffer for their family's financial freedom and the salvation of their children's - and the nation's - future. In Philippine literature, this dominant theme can be found in works like Aryo's Nanny Tales: Voices from the Diary of an Overseas Filipina Worker (2009) or Layosa's autobiographical account "Anywhere, Everywhere: The DH's Saga” (2000). In these stories, the characters' sense of fulfilment is often coupled with financial security and mediated through memories of home and familial attachments, and an imagined brighter future for their children (see also Tope 2016). Another dominant representation of the "Christ-like victim" is - as we will see - the imperilled Filipina body who has been subjected to gendered forms of abuse and violence.

The gendered tropes of heroic self-sacrifice are undoubtedly complicated by the conflation of motherhood ideologies - both state and religious - in the nation space. Domestic helpers carry a heavier burden of representation as there is a long tradition of associating women with the virtues of self-sacrifice due to the discourse of the Virgin Mary, also the country's official patron saint who is known as Dios Ina (God the Mother). This religious discourse is so powerful it has influenced state and social ideologies as well as literary representations of Filipina womanhood, sexuality, and even the nation. The archetypal Filipina woman whose virtues include "obedience and sacrifice, leading to self-effacement" (SabanpanYu 2011, 32) has been attributed to Rizal's creation of ideal womanhood in his acclaimed novel Noli Me Tangere (1887), Maria Clara, who is said to have been based on the Virgin Mary. The idealisation of the Filipina as Virgin Mary/ Maria Clara - both virgin and mother, suffering and self-sacrifice - has invariably influenced the shaping of Filipina sexuality, notably seen in social stereotypes of the chaste Filipina as "good" and the sexual, single woman as "indecent" or "bad" (Delgado-Infante and Ofreneo 2014, 393). Until today, the Filipina is widely expected by society to remain a virgin (until marriage) as a condition of honour, while premarital sex is regarded as a sin as well as a source of shame. The gendered implications of the Virgin Mary as a discourse are compounded when one realises that this figure is also instrumental to the narration of the Philippine nation. According to Pambid-Domingo (2011), the beautiful maiden-mother figure has historically been appropriated and transfigured into a "pure, merciful, caring, self-sacrificing weeping Inang Bayan" and eventually, "Inang Bayan-Pilipinas" (106); in Tagalog, Inang Bayan literally means "motherland" while Inang BayanPilipinas refers to Mother Philippines. The imagining of the Philippine nation as the feminine, nurturing mother that is protected by the father figures of the state and the masculinist state apparatuses in fact draws on a trope familiar to studies on 
nation and gender (Yuval-Davis 1997; for postcolonial Southeast Asian contexts, see Chin and Kathrina Mohd Daud 2017).

Although heavily circumscribed by multiple discourses that invoke the Virgin Mary - chastity, martyrdom, motherhood, motherland, migrant heroism - and exhorted by the state to remember their duties as "good" citizens and "good" women, domestic helpers abroad nonetheless have the choice to negotiate their identities and agency by either conforming to or resisting the ideological boundaries that maintain their disciplined state (Constable 1997). However, the negotiation process can be fraught with danger for the female OFWs whose dispossessed state and marginality in the liminal spaces of the global economy also place them in positions of sexual and physical vulnerability (on sexual threats to domestic helpers, see Constable 1997, 546-547). This point is made explicit by the tragic deaths of Flor Contemplacion, Delia Maga and Maricris Sioson in the 1990s; they represent cautionary tales of Filipina migrant workers whose bodies had suffered gendered forms of violence and ended up returning "home in a box" - the theme reflected in Soledad's Sister. Among the OFW deaths, it was Contemplacion's that most famously roused an entire nation to action. Filipinos took to the streets in mass protests, railing against the injustices that she suffered while criticising their government's inability to protect the OFW community abroad. While the ensuing media hype and national uproar surrounding these deaths visibly heightened the systematic devaluation of third-world migrant women as commodified, sexed bodies for sale in the global economy, the continued exploitation of these "Christlike victims" was ironically brought home through a spate of commercialised films in the 1990s ( $\operatorname{Lim} 2000$ ), which also reified the figure of the imperilled Filipina migrant body in the national imaginary.

As the coalescing forces of anger, frustration, and grief imploded within the nation space, the repetitive, circulating trope of the imperilled Filipina body was transformed into a symbolic site upon which the national memory of past hero-martyrs was resurrected, revealing in the process a traumatised nation still dwelling on the wounds of the past. The journalist Conrado de Quiros for instance, deliberately drew parallels between Contemplacion (a domestic helper convicted of murder and sentenced to death in Singapore) and Senator Benigno Aquino, Jr. (who was assassinated during the Marcos regime) based on their shared status as national martyrs by using the compelling language of violence and pain to describe the "wounded" nation: "The hole in [Aquino, Jr.'s] head became the mouth of the nation, the cracks in his skull became the screams of a wounded land," while "the welt around [Contemplacion's] neck became the mouth of a volcano, the ruptured veins in her face the screams of a strangled race" (quoted in Rafael 2000, 221). Through inflammatory analogies of rupture and injury, Contemplacion's 
death - and those that took place before and after hers - raised fearful images of a disempowered and emasculated state, helpless against the global violence aimed at the feminised body of Mother Philippines who, despite her repeated screams, was being "wounded" and "strangled".

In many ways, the gendered narrative of the imperilled and wounded Mother Philippines exposes the impotence of the masculinist government in its "inability or refusal to protect" the feminised and dispossessed bodies of the OFWs, the "socalled 'modern day heroes' who are in reality 'modern-day slaves"' (quoted in Rodriguez 2005, 13). Guillermo (2000) concurs, arguing that the state rhetoric of migrant heroism is "nothing but an ideology of submission and class oppression" and that the OFWs are "praised as heroes to make them better accept their place of servitude in society" (117). As the state rhetoric of migrant heroism is not "accompanied by institutional support" (Guillermo 2000, 116), the problematic split between ideological utterances and material reality and practice is thus revealed. At the same time, gender and sexual hypocrisies and inequalities can be observed in the treatment of Filipina migrant workers whose bodies are subjected to multiple injustices in transnational spaces: as sexed bodies, they are subjected to gendered forms of violence and abuse; as women citizens, they are subjected to the patriarchal state's economic priorities that limit their safety and protection; and as a gendered spectacle, they are once more exploited as media commodity through numerous films, all of which pander to the voyeuristic gaze of the patriarchal state by depicting the "spectacle of women done to death by eroticized violence" (Lim 2000, 148). Through these repetitive stories and media images, the ghosts of the imperilled migrant bodies return to haunt the nation, much like "spectral presences" trapped in between the liminal spaces of the transnational imaginary: "[n]either inside nor wholly outside the nation-state, they hover on the edges of its consciousness, rendering its boundaries porous" (Rafael 2000, 205).

Nevertheless, the ghosts that bear the burden of the migrants' grim realities must also be weighed against the material evidence of newfound migrant wealth in recent decades. Not surprisingly, these "spectral presences" are quickly dispelled by the amplification of positivist narratives in the nation space, of those OFWs who risked the dangers and returned flush with financial success, seen in the growth of suburbs, housing estates and luxury condominium projects. At the time of writing, the Philippines boasts two of Asia's largest shopping malls, attesting not only to a rapidly growing middle-class consumer base with sizeable purchasing power but also to the improved state of its national economy, epitomised by the soaring towers that dominate Manila's skyline. In 2015, then President Benigno Aquino III proudly commented on his country's remarkable economic transformation - from the "Sick Man of Asia" to the "Darling of Asia". With a 6.3 percent GDP growth, 
the Philippines was at the time the world's second fastest growing economy (Bacani 2015). As more of these rags-to-riches stories enter the imagination and vocabulary of the OFW, they also encourage Filipinas to go abroad and seek similar golden opportunities in the global market. In this game of chance, the helper's passage into international spaces is filled with both uncertainties and possibilities and, as my analysis will show, each crossing made will present choices that she must negotiate in order to realise her private hopes and dreams even as she braves the sexual perils in the patriarchal contexts of the global economy.

\section{Soledad's Sister: Dangerous Pleasures and Liminal Possibilities}

Soledad's Sister is a dark comedy of errors that revolves around transnational efforts to transport Soledad's corpse from Jeddah to her sister, Aurora, or Rory for short, in the Philippines, and the various characters involved in the (mis)handling of the "cargo" on the way: the self-serving Filipino vice-consul in Riyadh who had "mixed up his homebound corpses" (Dalisay 2008, 5), the apathetic cargo handlers and guards at the Ninoy Aquino International Airport, and the hapless policeman who fails to locate Soledad's body when it and his van are stolen from right under his nose. Along this absurdist journey, readers are introduced to an array of minor characters whose fleeting presences are belied by the emotional impact of their OFW-related narratives, such as the grieving family who arrives at the airport to collect the body of their loved one only to find it missing, or the story of Hana, a helper who commits suicide after she is raped and abused by her Malaysian employer, or the Filipina workers who gather in Hong Kong's Statue Square every Sunday and repeat the story of Hana among themselves. Together, these vignettes of migrant lives not only provide glimpses into the dangers and fears surrounding Filipina bodies, but also reveal the very limited agency that they possess. Indirectly too, the novel criticises the facile manner in which the state pays lip service to the discourse of the "national hero". Filled with imagery ranging from antiquated, non-computerised filing systems to bungling government staff and missing or misidentified OFW corpses, the novel satirises the bureaucratic inadequacies of the nation-state and its embedded layers of corruption, cronyism and nepotism. The comedic structure thus serves a vital function in magnifying the errors of the nation-state while exposing a crippled system that is unable to help the imperilled OFWs or even to guarantee their bodies' safe return to their families.

Despite its flippant tone, the novel's treatment of the imperilled Filipina migrant body is a grim one, for it invokes the nation's "spectral presences" from the very start, namely a missing OFW corpse and Soledad's unclaimed one just because "no one who should have known had been told that [the body] is there" (4). Even more unsettling is the callous manner in which Soledad's corpse is handled. Stripped 
of identity markers and personalised traits, her body is rendered inconsequential, viewed as an "it" rather than a "she," a "cargo" whose blankness serves as a metaphorical space upon which a label, "Drowned per forensic Jeddah" (4), is stuck. The novel in fact toys with the subversive image of a body-object that can be named, categorised and manipulated in any direction, a point highlighted when Soledad - whose passport is blacklisted - switches identities with Rory to obtain a contract to work in Saudi Arabia and cross international borders without incident. This switch not only creates further confusion when Soledad's corpse is (mis) identified as "Cabahug, Aurora V." (2) from Paez but the blurring of identities and bodies also heightens the textual tension when the reader is left to puzzle out the ambivalent meanings of the title. However, it is in the final pages that the mystery is deepened. Here, Dalisay offers one final - and perhaps most disturbing - twist when the reader discovers that there are in fact two missing helpers from the same household in Jeddah: Soledad and Meenakshi. However, only one body surfaces at the harbour, and its facial features are so badly damaged that a positive identification cannot be made: "If anyone had known her, they would not know her now" (192). By undermining the reader's assumption of truth, the open-ended conclusion raises even more disquieting questions due to the liminal, ambiguous properties posed by the "dead but not quite buried" (4) body. As a silent, blank metaphorical "third" space, the materiality of Soledad's body (or is it Meenakshi's?) posits the amorphous, in-between site upon which varying possible narratives and imaginings - whose body, what-ifs, and what-could-bes - are played out. Intrigued, the reader wants to know more about the gendered migrant body attached to the name of Soledad: What happened to her? Why did she die? Who is she really?

At the heart of the novel, then, is the mystery of Soledad as a (dead or missing) migrant body and as a character. Although central to the narrative, Soledad is an enigmatic figure whose inner motivations and desires are masked by acts of self-sacrifice and silence. In this, she is very different from her more attractive, articulate and confident younger sister, Rory, whose dream is to make it "out into the world" (39) as a successful singer. A troubled young woman who believes she caused the deaths of her parents and brother (they perished in a fire that went out of control while she was tending it), Soledad feels she "deserve[s] to be punished" and that "every pleasure was bound to be repaid in pain" (87). Consequently, she tries to atone for her guilt and sins through the Catholic rituals of prayer, penance, abstinence and self-denial: she withdraws into "a baleful silence" (104), refuses to eat, prays into the morning, and performs self-mutilation by "lancing little crosses into her wrist with a Gillette blade" (87). In time, she changes into a figure of "compulsive and crippling piety" (87) whose life is "spent in service and daily rosaries and litanies and sundry devotions" (104-105) to various saints. 
Her immersion in Catholic self-sacrifice is so complete that she "faded into nearobscurity" (104), literally embodying the silent, long-suffering Maria Clara as she "took everything that came her way with ... saintly gratitude" (104). Soledad "never complained" (104), not even when her aunt and uncle decided to stop her schooling so that "she could devote more time to [their] own children" (104). She ends up becoming a mother figure and maid to her young cousins, whom she cares for by "feeding and clothing and cleaning" (105) them. The reduction in status - from kin to domestic helper - is stressed when Soledad's household duties are extended to her sister, Rory, who soon perceives her as "more of a maid than a sister", and whose presence is likened to an insignificant "smudge on a white wall" (107).

By conforming to the stereotyped expectations of her family and religious community, Soledad develops the marginalised subject position and identity based on the discourses of martyrdom and motherhood. While displaced and reduced in position at home, her status is nonetheless elevated when she joins the ranks of the nation's heroic mothers in the diasporic, transnational contexts as a domestic helper. Employed by the Lau family in Hong Kong, Soledad replicates the structures of mothering in the new household by doing the housework, cooking and taking care of her employers' seventeen-year-old son, Hedison, and his ailing grandmother. Soledad once more adopts a saintly mien as she works through racial, linguistic and cultural differences while enduring the grandmother's abusive anger; through it all, she "hummed her songs of praise" (108) and "murmured devotions" (111). Being a domestic helper is just another form of penance and self-abnegation, with new terms written out for the conditions of her martyrdom, that "two years of uncomplaining labour would suffice to pay for all her sins" (99). While Soledad seemingly exchanges one life of duty and servitude for another in Hong Kong, one should still consider how her changed location and surroundings provide opportunities for self-exploration and new discoveries that go "beyond some scriptural admonition" (99), such as her newfound financial independence. Armed with a "new and positive focus for her life" (99), Soledad works hard to save enough money to buy a property in the Philippines and to ensure that Rory can finish her college education. However, while economic success is one that falls within the prescribed limits of the OFW discourse, her other, more implicit exploration of sexual pleasure does not.

Here, we come to the crux of Soledad's enigmatic character, for although she is depicted as a silent, heroic mother zealously committed to a life of selflessly caring for others, in truth, the reader knows very little of her subjective interiority, for she "never let[s] on her innermost passions and longings, if any, as if it were a crime to have one" (106). The layers of the mystery that is Soledad are slowly unpeeled 
through intermittent flashbacks that briefly illuminate the her interiority, revealing at its core the unpredictable vagaries of the human heart, an excess of feeling buried within latent sexual desires, and which fuels her fervid dreams for something more, something different. Prior to becoming a helper, Soledad would, in her rare moments of solitude, secretly indulge in her "consuming addiction to reading" (105), an activity that taps into her unspoken desire for agency while developing her interior life and imagined self. It is by vicariously feeding on the exotic yet exciting images of the foreign and the different that the "normally imperturbable Soledad had gone into a tizzy when a recruiter showed up in Paez promising jobs in Hong Kong and Singapore" (107). Although Soledad rationalises her departure as God's will, her body language speaks otherwise. Filled with purpose and driven by desire, her body visibly erupts into a frenzy of activity as she "secured herself a passport, cleaned out her room ... and taken the bus to Manila, staying there overnight ... before embarking on her first plane" (107) to Hong Kong. For a young woman who has lived her entire life in Paez and whose life has been given in service to others, Soledad's journey across transnational borders and spaces should be seen as an eloquent testament of her body's transformative potential and agentic possibilities.

Of note here is the manner in which the excess of Soledad's passions has a way of finding expression through the implicit language of her body, seen in acts that could potentially counter the hegemonic performative discourses of disciplined Filipina femininity and transnational motherhood. The ambiguous, double-edged properties of the migrant body-in-transition are nowhere clearer than when the reader realises that Soledad's inscrutable silence does not necessarily imply saintly self-sacrifice and submission but is instead reinterpreted as a defence mechanism that protects and hides her innermost feelings and thoughts. Hence, nobody truly knows what lies beneath Soledad's placid exterior, not even Rory, "who suddenly felt bereft, but of what, she wasn't sure" (107) when her sister suddenly departs for Hong Kong. In this manner, the novel overturns the reader's expectations time and again in a series of deconstructed moments and disconcerting twists as this stereotyped helper begins to emerge as one of the more fascinating characters in the novel.

In Hong Kong, Soledad's continued inner growth is visualised by her body's awakening sexual passion for Hedison, who is similarly exploring his own emerging sexuality, depicted as a lusty, "rampant urge to see if not to touch and feel a breathing female" (109). Within the constraints posed by ideological boundaries of race, class and culture, as well as the physically restrictive space of the small apartment and the inhibiting presence of the other family members, Soledad's and Hedison's unspoken yet mutual desires coalesce and "hung in 
the air between them" (152), while their heightened awareness of each other is experienced during ephemeral, thrilling moments in the intimate, liminal spaces of the apartment: she "would see Hedison through a break in his door", "when he slunk past her in the corridor..., the small towel around his waist" (109), or when he "brush[ed] against her backside in the passageway to the kitchen" (152). These dangerous, forbidden encounters constitute subversive and subjective "inbetween" moments when Soledad begins to break the constructed subject identity of the sexless heroic mother, a process that is further developed during her private mediations of "half-spoken" (112) thoughts and nebulous feelings; these are the key subjective moments when she is able to embrace her imaginative and sexual life as an essential part of her individual identity and voice:

I saw you in your room. I saw what you do in there. I think about it sometimes, but I don't know what to think about it. I feel things I don't know what I should do about. I've read about these things, ... butbut it's one thing to read and another to know, with your hands and fingers, the scope of God's creation. ... He tells me- he tells me I should stop trying to understand. I can know everything I want to know, but to understand - that's just for him to do. (112-113)

Although the growing sexual tension between Soledad and Hedison is complicated by the former's subordinate status in the household and the latter's age - both are troubling elements owing to the obvious vulnerabilities of their positions - the novel nonetheless refuses to portray them in a simplistic light as either victim or criminal. As the excerpt above shows, Soledad struggles not with the legalities of consent or even with religious morality, but with her own confused, "half-spoken" thoughts and feelings. Once again, it is her body's strong physical attraction to Hedison that tells a different story. By portraying sexual bodies that intuitively gravitate towards each other, the novel suggests that they possess unconscious impulses or knowledges that have yet to be fully processed by the mind, a point supported by Merleau-Ponty's phenomenological concept of the "lived" body (1962). This theory highlights the body's intrinsic ability to accumulate knowledge and produce meaning based on its embodied spatial and temporal experiences; this corpus of knowledge is then unconsciously internalised through the body's sensory and perceptual properties, known as "sense experience" (Merleau-Ponty 1962, 52), and projected through social behaviour and daily interactive practices. In the scene preceding the consummation of their mutual lust, the novel vividly describes the sensory acuity of the lived body that instinctively knows what it wants: 
Soledad listened, and began hearing other things - her own heartbeat, the rush of blood to her extremities, Hedison's pacing, the exhalation of the living room sofa as he sat on it, and again his rising and pacing, his lingering at her door. ... When the door opened and she could feel his feline presence at her feet, she inhaled just sharply enough for him to know that she knew he was there, without sending him away. She could sense him stopping and stiffening, like an animal with one paw upraised. (Dalisay 2008, 112-113)

In the excerpt above, we find that, while Soledad is not the one who initiates the encounter, she does nothing to reject Hedison either. In fact, she obliquely invites his advances by baring her leg while pretending to be asleep on her bed, a complicit act that both accommodates his desire and articulates her own. This uncharacteristic yet bold claiming of her own body's longings and the object of her sexual desire should be viewed as an empowering expression of an emerging identity that does not subscribe to pious motherhood, migrant heroism, sexual victimhood or even sexual rapaciousness, but has everything to do with affirming her own sexual, feminine power and sexual agency: "Soledad would remember that moment, and she would marvel at her boldness and the complete absence of guilt" (152).

In my earlier discussion, I noted that the migrant body, which is interwoven into the global symbolic systems of signification and power, also posits the reproductive and referential nexus of knowledge, practices and identities that informs the gendered processes of subjection and subjectivity in the shifting landscapes of global phallocentric economies. Yet the feminised migrant body-in-transition, as the material third space of multiple meanings and liminal possibilities, can also elude patriarchal attempts at signification and deconstruct the dominant narrative framework that inscribes her as marginal and powerless. Positioned in the inbetween spaces that intersect local and global, public and private trajectories of power, Soledad's sensory body engages alternative knowledge systems, as well as different identities, roles and relations that can potentially displace the binary hierarchies produced by the gendered tropes of migrant heroism and transnational motherhood. As her embodied explorations and negotiations of pleasure demonstrate, the migrant body posits an emerging hybrid space that powerfully dramatises the individual struggle for self-coherence and meaning, while precipitating the subjective transformations and developments in identity, agency, and voice, and in the process engenders something "new, surprising, unpredictable" (Grosz 1994, xi). 
Soledad's sexual awakening thus signals the beginning of a new inner life. While on the surface nothing has changed in terms of her role and status as a helper, inside, Soledad "had felt released from an inner bondage" (Dalisay 2008, 152), a shift that is visualised by the physiological changes of her body when she finds herself pregnant with Hedison's child. When her condition is discovered by her employer, Mrs. Lau, Soledad is forced to break her contract and return to the Philippines. Back home, she derives "great satisfaction" by falling back onto the same old patterns of attending "to Rory's needs" (155) and mothering her son, Nathan, albeit with a difference. For the first time in the sibling relationship, Soledad breaks her usual reticence and makes her "wants" clearly known: "I want you to finish college"; "I want to keep this house, I want Nathan to grow up and become an engineer" (156). The continuous changes in Soledad are underscored by a series of authoritative decisions that she makes for her family, such as buying a property in a new housing project and "furnishing it with every possible necessity and convenience", much to Rory's "consternation, because she never figured her Ate to be one moved by material compulsion" (155). At the same time, Soledad's subjective transformation is mirrored by the growing fecundity of her pregnant body, a phenomenon that deeply disturbs Rory, for she is unable to place this sexual single mother within the stereotyped frameworks of virtuous femininity and saintly motherhood. Rory demands to know whether Soledad had been abused or raped overseas, as though these are the only possible explanations for her condition. When Soledad refuses to give her any answers, Rory attempts to reinscribe her sister back into the familiar, dominant tropes of the overseas heromartyr by telling "her freshmen classmates, who were sure to tell their mothers, who were sure to tell their neighbours and friends, that Soledad Cabahug had been viciously assaulted by her Chinese employer in a moment of extreme helplessness, and that she deserved everyone's sympathy and respect" (156).

For all of Soledad's assertions of independence and the positive changes wrought by her explorations of agency and freedom in diasporic locations, the pleasure of transgressing the discursive limits posed by transnational tropes of heroic motherhood is not without its dangers. For instance, Soledad's transgressive pregnancy sows discord in her employer's household in Hong Kong, especially when Mrs. Lau, who immediately suspects her bewildered husband as the culprit, angrily threatens "to stab both Chester and Soledad - who had barricaded herself in her room while the storm blew over - with a stubby paring knife" (153). It is this threat to her personal safety that sends Soledad flying back to her country. When Soledad needs more money and decides to take another contract in Saudi Arabia, she is again faced with a crossroad where she has to choose between her domestic duties and a liberating evening of "fun" (191) with Meenakshi by meeting Yusuf and his friends. Even though Soledad negotiates this moment by doing "her duty, 
before everything else" (191), her decision to join Meenakshi "just once" (191) is nonetheless driven by her body's inarticulate yearnings, an excess of feeling that powerfully gestures towards freedom, agency and pleasure - those "vagrant longings [that] lifted her up above that corner, that room, that walled compound, far above her huddled self and dropped her into the living, throbbing heart of the city" (190). Within the misogynistic contexts of Saudi Arabia, where the Filipina migrant body is heavily circumscribed, Soledad's hopeful yet rebellious assertion of agency and freedom - made in a single, wrong choice - ultimately exacts a heavy cost: either death or disappearance.

\section{Conclusion}

Soledad's Sister both challenges and conforms to the dominant narratives of the heroic migrant mother. On the one hand, Soledad subverts expectations with her hybrid amalgam of "types" that do not fit the national discourse neatly - she is a hero-martyr who does her duty to her family, but she is also a sexual woman and a single mother, both of which are mediated individuated identities that challenge prescribed femininities in the Philippines. On the other hand, the novel also works to contain her subversive desires when she meets her tragic end, thereby maintaining the hegemonic patriarchal systems of the immigrant world. In this manner, the novel reveals the conflicting pull-push factors faced by every Filipina migrant worker, as the threat of sexual danger - the premise of woman's fear - is countered by the promise of financial and personal rewards - the basis of every migrant's dream. As the novel's ending makes clear, Soledad is not the first woman to negotiate these factors nor will she be the last. Rory too decides to leave the Philippines for a six-month stint as a vocalist at Saipan Marriott, but not before she convinces herself, "I am not my sister: what she failed to do, I will; and what she did, I will do better" (Dalisay 2008, 179). The title's ambiguous reference to both Soledad and her sister darkly hints at the exploitative and oppressive nature of migrant labour production, reflected in the "factory" line of anonymous Filipina bodies being reproduced and circulated for global consumption, and whose "names and faces didn't matter to anyone but the most punctilious clerk" (179).

At the same time, the dialectic of danger and pleasure is complicated by Soledad's subjective struggle for self-expression and agency, seen in her negotiation of identities and roles as she conforms to the authoritative tropes of Catholic martyrdom and Filipino motherhood while exploring the potentially deviant yet pleasurable paths led by her own inchoate desires in the in-between spaces of the global economy. At the centre of these explorations is the ambiguous migrant bodyin-transition, an embodied third space where liminal possibilities are manifested, including different imaginings, transformative identities, and the empowering 
affirmations of voice and agency. Yet the novel's tragic end also confirms that the sexually active and transgressive female migrant body is especially vulnerable to danger in the global economy. Narrowly circumscribed and objectified by the male gaze either through commercialised voyeurism or state surveillance, the female body and its sexuality are labelled, commodified, and disciplined by multiple discourses that highlight the tacit collusion between local and global masculinist governments as they mutually reinforce the gendered structures of inequality through the continued disenfranchisement and victimisation of third-world migrant women workers.

Within the nation-space, the apathetic impotence of the Filipino government and its incapacity to aid the imperilled helper is masked by the state's manipulative revisions of the victim as migrant hero in the national imaginary. At the same time, the novel also suggests that, for as long as these injustices and abuses exist, the "spectral presences" of imperilled Filipina migrant bodies will keep returning to haunt the nation, much like the unknown OFW corpse that the authorities claim is Soledad's. This point is brought home when the corpse is stolen by a thief, Jose Maria, who, in a series of unfortunate blunders, falls into the river together with the coffin and drowns. Days later, his body surfaces and with it "the gas-leavened casket of a woman's body, broken free of its wooden cage and of the fine primordial mud" (179). By refusing to stay "buried" and by repeatedly rising from the watery depths - once in Jeddah and again in the Philippines, the twice-resurrected body of the "Christ-like" helper - with its symbolic links to the suffering, wounded and violated Mother Philippines - undermines the hopeful tropes of salvation and redemption of the country, becoming instead a recurring national nightmare in which the "same old story" keeps reinscribing and re-enacting itself with every Filipina migrant worker who enters the capitalistic-patriarchal spaces of the global economy.

\section{References}

Aryo, A.D. 2009. Nanny tales: Voices from the diary of an overseas Filipina worker. Philippines: ResearchMate Inc.

Bacani, L. 2015. Aquino tells Pinoys in Chicago: Philippines now 'Darling of Asia'. The Philippine Star. 7 May.

Bhabha, H.K. 1990. The third space: Interview with Homi Bhabha. In Identity: Community, culture, difference, ed. J. Rutherford, 207-221. London: Lawrence \& Wishart.

Butler, J. 1990. Gender trouble: Feminism and the subversion of identity. New York: Routledge.

Chin, G.V.S. and Kathrina Mohd Daud (eds.). 2017. The Southeast Asian woman writes back: Gender, identity, and nation in the literatures of Brunei Darussalam, Malaysia, Singapore, Indonesia and the Philippines. Singapore: Springer. 
Constable, N. 1997. Sexuality and discipline among Filipina domestic workers in Hong Kong. American Ethnologist 24(3): 539-558. https://doi.org/10.1525/ ae.1997.24.3.539

Dalisay, J. 2008. Soledad's sister. Philippines: Anvil Publishing.

Dalisay, J.Y. 2010. Interview by Daryll Delgado. Kritika Kultura 14: 171-181.

Dalisay, Jr., J. 2007. Literature and contemporary Philippine politics. Kyoto Review of Southeast Asia 8-9 (March). https://kyotoreview.org/issue-8-9/literature-andcontemporary-philippine-politics/ (accessed 18 November 2017).

Delgado-Infante, M.L. and Ofreneo, M.A.P. 2014. Maintaining a "good girl” position: Young Filipina women constructing sexual agency in first sex within Catholicism. Feminism \& Psychology 24(3): 390-407.

Ezer, T., Joyce, A., McCalley, P. and Pacamalan, N. 2011. Protecting women's human rights: A case study in the Philippines. Human Rights Brief 18(3): 21-27.

Grosz, E. 1994. Volatile bodies: Toward a corporeal feminism. Bloomington: Indiana University Press.

Guillermo, A.G. 2000. The Filipina OCW in extremis. In Geopolitics of the visible: Essays on Philippine film cultures, ed. R.B. Tolentino, 106-124. Quezon City: Ateneo de Manila University Press.

Lim, B.C. 2000. True fictions, women's narratives, and historical trauma. In Geopolitics of the visible: Essays on Philippine film cultures, ed. R.B. Tolentino, 145-161. Quezon City: Ateneo de Manila University Press.

Layosa, L.R. 2000. Anywhere, everywhere: The DH's saga. In From America to Africa: Voices of Filipino women overseas, ed. L. Kalaw-Tirol, 150-163. Philippines: Fai Resource Management Inc.

Merleau-Ponty, M. 1962. Phenomenology of perception (Trans. by C. Smith). London: Routledge \& Kegan Paul.

Pambid-Domingo, T. 2011. Dios Ina (God the Mother) and Philippine nationalism. From wilderness to nation: Interrogating bayan, ed. D.L. Woods, 87-107. Diliman, Quezon City: The University of the Philippines Press.

Parreñas, R.S. 2001a. Servants of globalization: Women, migration, and domestic work. Stanford, California: Stanford University Press.

2001b. Mothering from a distance: Emotions, gender, and intergenerational relations in Filipino transnational families. Feminist Studies 27(2): 361-390. https://doi.org/10.2307/3178765

2001c. Transnational mothering: A source of gender conflicts in the family. North Carolina Law Review 88: 1825-1856.

2005. Children of global migration: Transnational families and gendered woes. Stanford, California: Stanford University Press.

. 2008. The force of domesticity: Filipina migrants and globalization. New York: New York University Press.

Philippine Statistics Authority. 2018. 2017 survey on overseas Filipinos (results from the 2017 survey on overseas Filipinos). http://psa.gov.ph/content/2017-surveyoverseas-filipinos-results-2017-survey-overseas-filipinos/ (accessed 18 May 2018).

Rafael, V.L. 2000. White love and other events in Filipino history. Durham, NC: Duke University Press. 
Rodriguez, R.M. 2002. Migrant heroes: Nationalism, citizenship and the politics of Filipino migrant labor. Citizenship Studies 6(3): 341-356. https://doi.org/ 10.1080/1362102022000011658

2005. Domestic insecurities: Female migration from the Philippines, development and national subject-status. Working Paper 114, Center for Comparative Immigration Studies, University of California Berkeley, San Diego, California.

Sabanpan-Yu, H. 2011. Bridging cultures: The migrant Philippine woman in the works of Jessica Hagedorn, Fatima Lim-Wilson and Sophia Romero. Philippines: National Commission for Culture and the Arts (NCCA).

Tadiar, N.X.M. 2005. Filipinas 'living in a time of war'. In Pinay power, feminist critical theory: Theorizing the Filipina/American experience, ed. M.L. de Jesús, 373-385. New York: Routledge.

Tolentino, R.B. 2011. Vaginal economy: Cinema and sexuality in the post-Marcos, post-Brocka Philippines. Positions: East Asia Cultures Critique 19(2): 229-256. https://doi.org/10.1215/10679847-1331706

Tope, L.R. 2016. Glocalising cultural desire: Texts on the overseas Filipina worker (OFW). Kemanusiaan the Asian Journal of Humanities 23(Supp. 2): 119-136. https://doi. org/10.21315/kajh2016.23.s2.7

Yuval-Davis, N. 1997. Gender and nation. London: Sage Publications.

Vance, C. 1984. Pleasure and danger: Toward a politics of sexuality. In Pleasure and danger: Exploring female sexuality, ed. C. Vance, 1-27. London, Pandora Press. 